Chapter 3

\title{
Power Generation and Cross-border Grid Planning for the Integrated ASEAN Electricity Market: A Dynamic Linear Programming Model
}

\section{Youngho Chang}

Nanyang Technological University

\section{Yanfei Li}

Nanyang Technological University

August 2012

This chapter should be cited as

Cheng, Y. and Y. Li (2012), 'Power Generation and Cross-border Grid Planning for the Integrated ASEAN Electricity Market: A Dynamic Linear Programming Model' in Wu, Y., X. Shi, and F. Kimura (eds.), Energy Market Integration in East Asia: Theories, Electricity Sector and Subsidies, ERIA Research Project Report 2011-17, Jakarta: ERIA, pp.37-58. 


\title{
Chapter 3
}

\section{Power Generation and Cross-border Grid Planning for the Integrated ASEAN Electricity Market: A Dynamic Linear Programming Model}

\author{
Youngho Chang \\ Nanyang Technological University, Singapore \\ YANFEI LI \\ Nanyang Technological University, Singapore
}

The central question raised in this study is how to meet the growing power demand in ASEAN countries in the next two decades. Uneven distribution of energy resources and uneven paces of economic development among ASEAN countries complicate the question. The ASEAN Power Grid (APG) that interconnects all ASEAN countries and enables cross-border power trade could potentially provide cost-saving solutions. This study builds a dynamic linear programming model and simulates optimal development paths of power generation capacities in ASEAN countries. Scenarios are built around the assumptions about the power trade policy regimes. It is found that more open power trade regime encourages more development of renewable sources of power generation, and accrues more savings in the total cost of meeting the growing future power demand from 2010 to 2030. 


\section{Introduction}

Electricity demand in the ASEAN region is projected to grow 6.1\%-7.2\% per annum. At such speeds, it would arrive at 3-4 times of current level by 2030 (Institute of Energy Economics, Japan et al., 2009). Comparing to the Asia Pacific region as a whole for which the electricity demand grows at 3.4\% per annum (ADB, 2009), ASEAN's demand for electricity is growing especially fast, thanks to the exceptionally high economic growth prospect of the region.

Meeting such high growing demand will be extremely challenging although ASEAN countries are considered rich in energy resources. It is estimated that the ten member countries of ASEAN have 22 billion barrels of oil reserve, 227 trillion cubic feet of natural gas reserve, 46 billion tons of coal reserve, 234 gigawatts of hydropower potential and 20 gigawatts of geothermal capacity (ASEAN Ministers on Energy Meeting, 2004). However, the distribution of the resources is unbalanced. Most of the hydropower resource is located within the Greater Mekong Subregion that includes Cambodia, Lao PDR, Myanmar, and Viet Nam, as well as Yunnan and Guangxi Provinces in southern China. Coal resource concentrates in Indonesia and Malaysia. Most of the gas and oil reserves are in Malaysia and Indonesia. Apart from uneven energy resource endowment, the unbalanced level of economic development among the ASEAN countries adds to the difficulty in utilizing these resources to meet the fastgrowing electricity demand (Atchatavivan, 2006).

In vision of the above situation, an ASEAN power grid that links the energy resource-rich and the energy resource-poor countries could potentially play an important role in reducing the overall cost to the region to meet its growing electricity demand. The ASEAN 2020 Vision adopted in 1997 by the heads of state at the $2^{\text {nd }}$ ASEAN Informal Summit held in Kuala Lumpur envisioned an energy-interconnected Southeast Asia through the ASEAN Power Grid and the Trans-ASEAN Gas Pipeline Projects. A working group was established in 2000 to undertake an ASEAN Interconnection Master Plan Study (AIMS), completed in 2003. Based upon an optimization study, eleven potential power grid interconnection projects were selected for potential implementation through 2020. The Heads of ASEAN Power Utilities/Authorities (HAPUA), a specialist organization under the ASEAN Center for Energy (ACE), monitors the implementation 
of the Power Grid (Atchatavivan, 2006).

The quantitative analysis of regional power market integration in ASEAN has not been studied extensively, and a few existing studies have focused on the institutional and policy aspects of regional development in relation with energy cooperation. $\mathrm{Yu}$ (2003) discussed the policy and institutional barriers to the formation of the Greater Mekong Sub-region (GMS) energy cooperation. Economic Consulting Associates (2010) provides an update on the progress of GMS power market integration. Adopting the Purdue Electricity Trade Model - a cost minimization model for energy resource planning, Yu, et al. (2005) assess the potential of hydropower development and free power trade between China and ASEAN countries. Watcharejyothin \& Shrestha (2009) develop a simulation model to analyze the power development planning of Lao PDR and Thailand and explore the power trade opportunities between the two countries, focusing on hydropower. In sum, a systematic analysis on the planning of power development and the economic benefits with an integrated ASEAN power market has not been conducted.

This study serves to quantify the economic benefits of the ASEAN power grid, as well as to propose an optimized development plan of power generation capacity in the region, based on the ASEAN Power Grid (APG). Accordingly the purposes of this study are on the one hand to justify the investments on the ASEAN Power Grid, and on the other hand to identify the priorities in developing new power generation capacity and transmission lines to meet the growing demand over time. For these purposes, a dynamic linear programming model is built to simulate the demand and supply of electricity in the ASEAN region in the next few decades. The following section presents more details about our methodology.

\section{Methodology}

Answering how to prioritize increasing generation capacity and expanding grid networks, this study applies a well-established dynamic linear programming model to the power planning of the ASEAN countries for the next few decades, assuming that the corresponding ASEAN Power Grid infrastructure would be in place. In this way, this 
study delivers implications on the optimal timing of investment in both the power generation capacity and the cross-border power grid infrastructure. In our framework, being optimal would imply the least cost of power generation while catering to meet the growing electricity demand.

This study intensively scans and collects data about exploitable energy resources in each member country of ASEAN as well as the operation cost and capital cost of monetizing the resources for power generation using different technologies. Our dynamic linear programming algorithm suggests the optimal timing of investing and monetizing each type of energy resource of the ASEAN countries.

A few scenarios are constructed to reflect different assumptions about power trade policies: no power trade, $20 \%$ of demand allowed to be met by power trade, and $50 \%$ of demand allowed to be met by power trade.

The study adopts a dynamic linear programming framework in power generation first developed by Turvey \& Anderson (1977) and later adapted by Chang \& Tay (2006). In this study, significant extensions of the original models are made. A new country dimension is added to allow an international framework with cross-border electricity trade. The new model also adds the cost of cross-border power transmission as well as transmission loss into account. Last but not least, the model covers the issue of carbon emissions from power generation as well as the carbon cost of power generation. The model is solved using General Algebraic Modelling System (GAMS).

The study serves two important purposes, one of which is to examine the least-cost development of different types of energy resources using dynamic optimization and the other is to comprehensively scan alternative combinations of energy resources needed for power generation in each time period.

In such a model, taking a long-time horizon, the planner's objective is to choose plant capacities and outputs so as to minimize the present value of total costs. ${ }^{1}$ The levelized cost of generating electricity is therefore embedded in this model. The sets of constraints to be satisfied are as follows. First, available installed capacity needs to be sufficient to meet the expected peak demand plus an allowance for demand above expected levels. Second, the total plant output must be sufficient to meet the

\footnotetext{
${ }^{1}$ The model is one with cost-minimization of power development planning over long-time horizon. Unlike a dynamic CGE model, it does need to assume a steady state solution.
} 
instantaneous power demand levels. Third, the output from each plant cannot exceed its available capacity.

Adapting and modifying the dynamic linear programming framework, this study quantifies external economic, technological, and institutional shocks in different scenarios and develops power planning strategies accordingly.

\section{Model Description}

\section{CAPEX}

The following models the capital expenditure (CAPEX) of a certain type of power generation capacity at a certain point of time. Let $x_{\text {miv }}$ be the capacity of plant type $m$, vintage $v,{ }^{2}$ in country $i$ and $c_{m i v}$ be the corresponding capital cost per unit of capacity of the power plant. So the total capital cost during the period of this study would be $\sum_{i=1}^{I} \sum_{v=1}^{T} \sum_{m=1}^{M} c_{m i v} * x_{m i v}$ (In GAMS code, for consistency in presentation with the other cost terms, we add a time dimension to the equation besides the vintage dimension. By doing that, we amortize capital cost using a capital recovery factor).

\section{$\underline{O P E X}$}

The following models the operational expenditure (OPEX) of a certain type of power generation capacity at a certain point of time. Let $u_{\text {mijtvp }}$ be power output of plant $m$, vintage $v$, in year $t$, country $i$, block $p$ on the load, and exported to country $j$. Let $F_{\text {mitv }}$ be the corresponding operating cost which varies with $v$, and $\theta_{j p}$ be the time interval of load block $p$ within each year in the destination country. Opex $(t)$ in year $\mathrm{t}$ is expressed as $\sum_{i=1}^{I} \sum_{j}^{J} \sum_{v=-V}^{t} \sum_{p=1}^{P} \sum_{m=1}^{M} F_{m i t v} * u_{m i j t v p} * \theta_{j p}$.

\section{Carbon Emissions}

The model considers carbon emissions of different types/technologies of power generation capacity and takes the cost of carbon emissions into consideration. Let $c e_{m}$

\footnotetext{
${ }^{2}$ Vintage indicates the time a certain type of capacity is built and put into use.
} 
be the carbon emissions per unit of power plant capacity of type $j$ plant, and $c p_{t}$ be the carbon price per unit of carbon emissions in year $t$. The amount of carbon emissions produced are expressed as $\sum_{m=1}^{M} \sum_{i=1}^{I} \sum_{j=1}^{J} \sum_{v=-V}^{T} u_{m i j t v p} * \theta_{j p} * c e_{m}$, and carbon cost in year $t$ is $C C(t)=c p_{t} *\left(\sum_{m=1}^{M} \sum_{i=1}^{I} \sum_{j=1}^{J} \sum_{v=-V}^{T} u_{m i j t v p} * \theta_{j p} * c e_{m}\right)$.

\section{Cross-border Transmission Cost}

The costs of cross-border transmission come in two forms. One is the tariff paid to recover the capital investment and operational cost of the grid line. The other is the transmission loss, which could be significant if the distance of transmission is long. To model the tariff of transmission, let $t p_{i, j}$ be the unit MWh transmission cost of power output from country $i$ to country $j$. Let $T C(t)$ be the total cost of cross-border power transmission in year $t$, we have $T C(t)=\sum_{i=1}^{I} \sum_{j=1}^{J} \sum_{v=-V}^{T} \sum_{p=1}^{P} u_{m i j t v p} * \theta_{j p} * t p_{i, j}$.

\section{Objective function}

As discussed earlier in the methodology section, our objective is to minimize the total cost of electricity during the period of this study. The objective function is written as:

$$
o b j=\sum_{i=1}^{I} \sum_{v=1}^{T} \sum_{m=1}^{M} c_{m i v} * x_{m i v}+\sum_{t=1}^{T}\{O p e x(t)+C C(t)+T C(t)\}
$$

\section{Constraint conditions}

Optimizing the above objective function is subject to the following constraints. Equation (2) shows a first set of constraints, which require total power capacity to meet total power demand in the region. Let $Q_{\text {itp }}$ be the power demand of country $i$ in year $t$ for load block $p$.

$$
\sum_{i=1}^{I} \sum_{j=1}^{J} \sum_{m=1}^{M} \sum_{v=-V}^{t} u_{m i j t v p} \geq \sum_{i=1}^{I} Q_{i t p}
$$

The second one, shown in equation (3), states the constraint of load factor $l f_{m i}$ of each installed capacity of power generation. Let $k i t_{m i}$ be the initial vintage capacity of type $m$ power plant in country $i$.

$$
u_{m i j t v p} \leq l f_{m i} *\left(k i t_{m i}+x_{m i v}\right)
$$


The third constraint, shown in equation (4), says that power supply of all countries to a certain country must be greater than the country's power demand. Let $t l_{i, j}$ be the ratio of transmission loss in cross-border electricity trade between country $i$ and country $j$.

$$
\sum_{j=1}^{J} \sum_{m=1}^{M} \sum_{v=-V}^{t} u_{m i j t v p} \cdot t l_{i j} \geq Q_{i t p}
$$

Equation (5) states that total supply of power of one country to all countries (including itself) must be smaller than the summation of the country's available power capacity at the time.

$$
\sum_{j=1}^{J} u_{m i j t v p} \leq \sum_{m=1}^{M} \sum_{v=-V}^{t} l f_{m i} *\left(k i t_{m i}+x_{m i v}\right)
$$

The fifth constraint, shown in equation (6), is capacity reserve constraint. Let $p r$ be the rate of reserve capacity as required by regulation. And let $p=1$ represent the peak load block.

$$
\sum_{i}^{I} \sum_{m=1}^{M} \sum_{v=-V}^{t} l f_{m i} *\left(k i t_{m i}+x_{m i v}\right) \geq(1+p r) * \sum_{i}^{I} Q_{i t, p=1}
$$

Specifically, hydro-facilities have the so-called energy factor constraint as shown in equation (7). Let $e f_{m i}$ be the energy factor of plant type $m$ in country $i$. Other facilities will have $e f=1$.

$$
\sum_{p=1}^{P} \sum_{j=1}^{J} u_{m i j t p} \leq e f_{m i} *\left(k i t_{m i}+x_{m i v}\right)
$$

Lastly, development of power generation capacity faces resource availability constraint, which is shown in equation (8). Let $X M A X_{m i}$ be the type of resource constraint of plant type $m$ in country $i$.

$$
\sum_{v=1}^{T} x_{m i v} \leq X M A X_{m i}
$$

\section{Data Description}

\section{Range}

This study covers the ten member countries of ASEAN, which are Brunei, 
Cambodia, Indonesia, Lao PDR, Malaysia, Myanmar, Philippines, Singapore, Thailand, and Viet Nam. ${ }^{3}$ Technologies or means of power generation covered in this study include coal, diesel, natural gas, hydro, geothermal, wind, solar PV, and biomass. ${ }^{4}$

\section{$\underline{\text { Data Inputs }}$}

The main items of data required for this study include existing capacities of the mentioned types of power generation, the CAPEX and OPEX of these types of power generation, the load factor and life expectancy of each vintage of each type of power generation, the energy resources available for power generation in each country, the peak and non-peak power demand and duration of power demand of each country, projected growth rate of power demand, and transmission cost and transmission losses of cross-border power trade.

Data are collected from the Energy Information Administration (EIA), the International Energy Agency (IEA), the Heads of ASEAN Power Utilities/Authorities (HAPUA), the ASEAN Center for Energy (ACE), the World Energy Council (WEC), the Solar and Wind Energy Resource Assessment project, and other country-specific sources. Detailed data and sources of data are presented in Appendix A from Table A1 to Table A5.

\section{Scenario Parameters}

Growth in power demand is derived from the Third ASEAN Energy Outlook. Different countries grow at their own paces, from 2010 to 2030, as shown in Table $1 .^{5}$

\footnotetext{
${ }^{3}$ It is understood by the authors that Yunnan province of China has been conducting cross-border power trade with Viet Nam and Lao PDR. However, the maximum of the power trade between Yunnan and Viet Nam is 800MW, and in the case of Lao PDR it is much smaller. We therefore think these cross-border power trade activities are not going to bring major impacts to the pattern of crossborder power trade within ASEAN, as estimated by our model.

${ }^{4}$ Nuclear is not covered in the scope of this study for two reasons. First, after the Fukushima nuclear power station accident, the attitude of the world has changed drastically against nuclear power generation. Second, the risks embedded with nuclear power generation are hard to estimate and therefore not reflected in the data about its costs reported publically.

${ }^{5}$ If legitimate forecasts on the growth of power demand are available, a kind of sensitivity analysis such as lower growth or higher growth cases could be done. As the focus of this research, however, is to examine the impact of regional power trade policy regime and corresponding power development planning, it does not consider alternative growth rates of power demand.
} 
Table 1: Growth Rate of Power Demand in ASEAN Countries

\begin{tabular}{lc}
\hline & Growth Rate (\%) \\
\hline \hline Brunei & 1.2 \\
Cambodia & 9.9 \\
Indonesia & 3.9 \\
Lao PDR & 7.7 \\
Malaysia & 4.5 \\
Myanmar & 9.0 \\
Philippines & 4.5 \\
Singapore & 4.2 \\
Thailand & 4.9 \\
Viet Nam & 6.7 \\
\hline
\end{tabular}

Sources: The Third ASEAN Energy Outlook

Projections of future economic activity are always built on assumptions of different scenarios. In this model, the parameters to reflect different visions about future technology evolutions and social and economic trends include the growth rate of OPEX, the growth rate of CAPEX, the growth rate of carbon emissions costs, and the growth rate of power demand in each country.

Our assumptions on the rate of changes of OPEX and CAPEX are assumed as in Table 2. The growing costs of power generation from coal, diesel, and gas reflect the common understanding that the prices of fossil fuel will keep increasing in the future. The declining costs of power generation from hydropower, geothermal, wind, and Solar PV reflect the common expectation that renewable energy technologies will keep improving and therefore bring down costs in the future.

Table 2: Rate of Changes of OPEX and CAPEX

\begin{tabular}{lc}
\hline & Rate of Changes $(\%)$ \\
\hline Coal & 2.1 \\
Diesel & 1.26 \\
Natural Gas & 1.36 \\
Hydro & -0.5 \\
Geothermal & -0.5 \\
Wind & -1.4 \\
Solar PV & -4.6 \\
Biomass & 0.3 \\
\hline
\end{tabular}

Sources: EU SEC (2008) 
Other parameters include carbon cost, preservation rate, and discount rate. Carbon cost is set to start from current European market price at USD 8/ton of $\mathrm{CO}_{2}$ emissions and is assumed to increase at an annual rate of $10 \%$. Preservation rate, as referred to in equation (6), is assumed to be $20 \%$. And discount rate, which is important in determining the estimated LCOE, is set at 5\%. Carbon emissions parameter for each type of power generation is taken from Varun, et al. (2009).

The percentage of demand to be met by power trade is the key parameter in distinguishing the three scenarios we estimate. The first one is a scenario without any power trade, and the percentage is set to be equal to zero. The second one is a scenario with $20 \%$ of demand allowed to be met by power trade. And the third one is a scenario with $50 \%$ of demand allowed to be met by power trade. ${ }^{6}$

\section{Simulation Results and Findings}

Our simulation results indicate that with the Business As Usual (BAU) projection of power demand from 2010 to 2030, the ASEAN power grid enables active cross-border power trade between countries rich in resources and countries with high demand. The total cost to meet the growing electricity demand during 2010-2030 is reduced by around $3.9 \%$ with cross-border power trade enabled by the ASEAN power grid in the $50 \%$ power trade scenario, as compared to the no power trade scenario in which each country struggles to build high cost power generation capacity to meet its own demand. In absolute terms, this savings is equivalent to USD 29 billion.

In addition to the quantified benefits of the ASEAN power grid in terms of cost savings, the results are also expected to imply which type of power generation capacities should be prioritized and built over time, as the following three figures show. Each of the three figures shows the optimal path of development of new power generation capacities under the corresponding scenario, which assumes different policy

\footnotetext{
${ }^{6} \mathrm{~A}$ free power trade scenario was considered but is not reported here as it is too hypothetical and its results could be distorted by the concern of so called "home preference bias" in power supply and energy security.
} 
regimes on cross-border power trade within the ASEAN region.

In this way, the results of this study not only quantify the direct economic benefits of the ASEAN power grid but also indicate the practical path of power generation capacity development to make best use of the ASEAN power grid infrastructure.

\section{Figure 1: Accumulated Power Generation Capacities of All ASEAN Countries in the No Power Trade Scenario (Unit: MW)*}
(a) Thermal Power Generation
(b) Renewable Energy for Power Generation
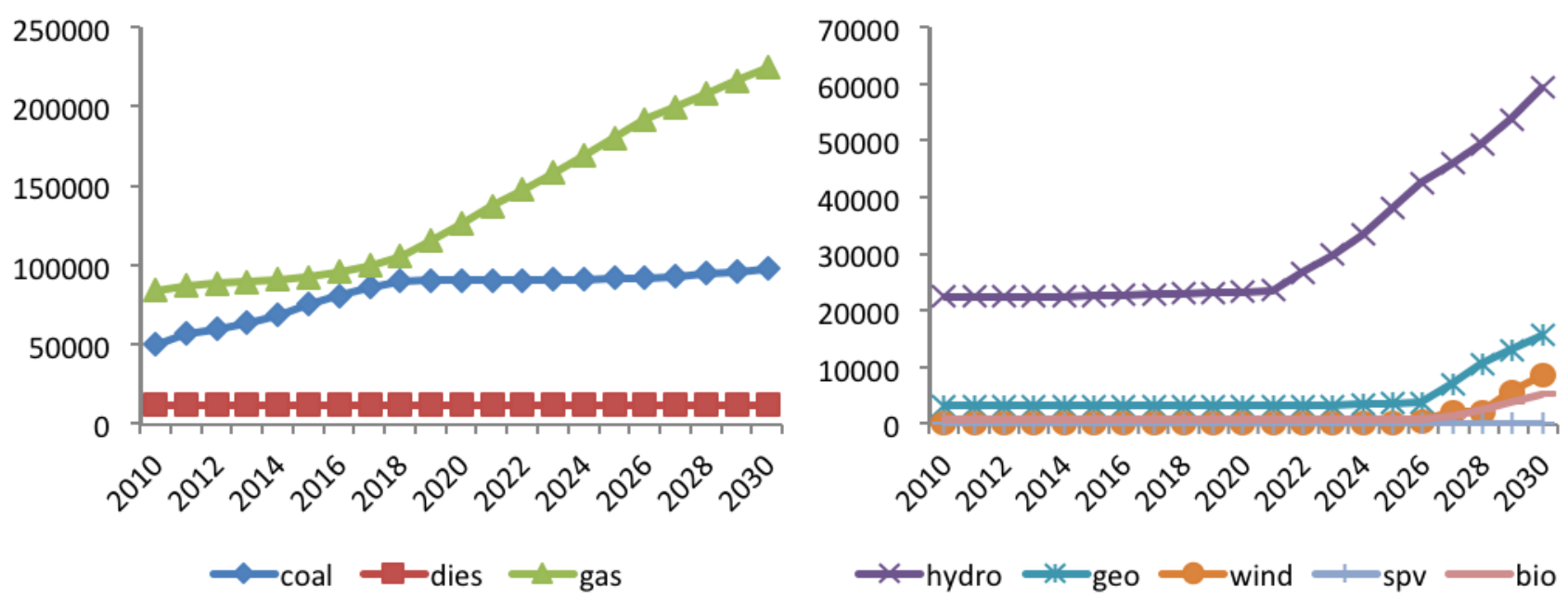

Note: * "Coal" stands from coal-fired power plants; "Dies" stands for diesel-fired power plants; "Gas" stands for natural gas-fired power plants; "Hydro" stands for hydropower; "Geo" stands for geothermal power plants; "Wind" stands for wind power; "spv" stands for solar PV power generation; and "bio" stands for biomass-fired power plants.

Figure 1 presents which type of power generation capacity should be developed at what time and with what amount, when no power trade is allowed. The left panel presents the development of fossil fuel-based power generation while the right panel presents the development of renewable energy for power generation. It is observed that future power generation in the ASEAN region will be dominated by natural gas and coal in the next two decades. New hydropower capacity is not being developed until 2022, and total new hydropower capacity is about $37 \mathrm{GW}$ by 2030. Other renewable energy such as wind, geothermal, and biomass will be developed, but at much smaller scale. Solar PV sees no new development at all.

The exceptionally high growth in natural gas-fired and coal-fired power generation capacities is partially driven by high growth in power demand in the ASEAN countries. 
While demand is growing fast, the fact that, in this scenario, countries that lack in renewable energy sources are not able to access other cheap renewable energy sources from other resource-rich countries such as hydropower, geothermal and wind power is the other important reason. They are forced to build more natural gas-fired and coalfired power generation capacities to meet growing domestic demand.

\section{Figure 2: Accumulated Power Generation Capacities of All ASEAN Countries in the $20 \%$ Power Trade Scenario (Unit: MW)}

(a) Thermal Power Generation

(b) Renewable Energy for Power Generation
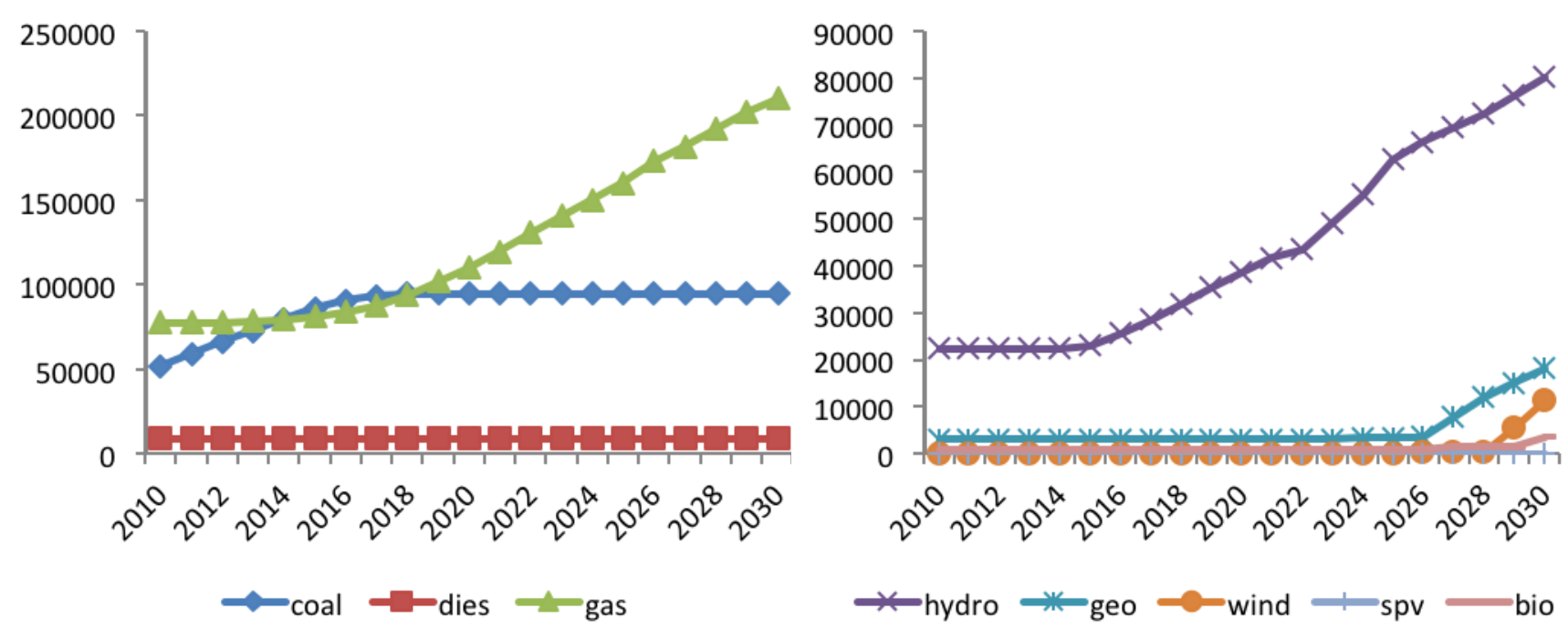

Figure 2 presents the type of power generation capacity to be developed over time in the scenario where $20 \%$ of each country's power demand is allowed to be met by power trade. It is observed that new hydropower is being developed as early as 2016, and total new capacity reaches about $58 \mathrm{GW}$ by 2030 . Total new coal-fired and natural gas-fired capacities are slightly reduced, as they are substituted mainly by hydropower. ${ }^{7}$ The implication is that by opening power trade within the region, countries are able to draw cheaper hydropower from the countries in the Greater Mekong Subregion such as Lao PDR and Cambodia. Although the growth in demand remains unchanged in the ASEAN countries in this scenario, resource-rich countries could build more hydropower,

\footnotetext{
${ }^{7}$ Later we show that other renewables including geothermal and wind power generation also contribute to the substitution of fossil fuel-fired power generation capacities.
} 
geothermal, and wind capacities and export power to resource-poor countries. The imported power thus substitutes a significant amount of new fossil fuel-fired power generation capacities otherwise to be built in the resource-poor ASEAN countries.

The second scenario reduces the total cost to meet the growing electricity demand during 2010-2030 by $3 \%$, as compared to the total cost incurred in the first scenario without any power trade. In absolute terms, the savings amount to USD \$20.9 billion.

\section{Figure 3: Accumulated Power Generation Capacities of All ASEAN Countries in the $50 \%$ Power Trade Scenario (Unit: MW)}

(a) Thermal Power Generation

(b) Renewable Energy for Power Generation
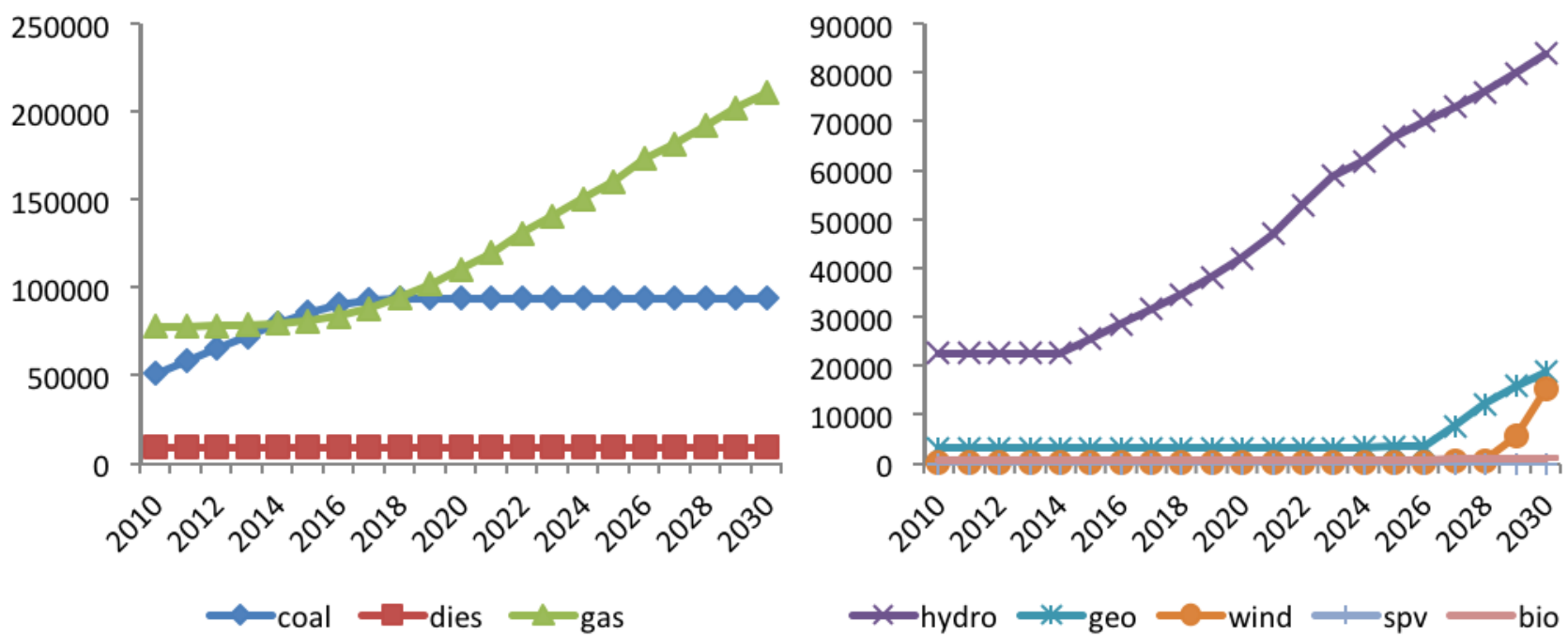

Figure 3 presents the type of power generation capacity to be developed over time in the scenario where $50 \%$ of each country's power demand is allowed to be met by power trade. It is observed that the large-scale development of new natural gas-fired power plants is delayed to 2015. The development of new hydropower is brought forward to 2015, one year earlier as compared to the previous scenario. Total new hydropower capacity would reach over $61 \mathrm{GW}$ by 2030 . The implication is that more open power trade in the region would allow countries to draw more and cheaper hydropower from the Greater Mekong Subregion as well as from Malaysia.

Table 3 gives more details about the additional power generation capacities to be built over the period of 2010 to 2030, in the three simulated scenarios. 
Table 3: Development of Additional Capacities in the Three Simulated Scenarios

\begin{tabular}{lcccccc}
\hline & \multicolumn{2}{c}{ No Trade } & \multicolumn{2}{c}{$\mathbf{2 0 \%}$ Power Trade } & \multicolumn{2}{c}{$\mathbf{5 0 \%}$ Power Trade } \\
\hline & $\begin{array}{l}\text { Number of } \\
\text { Countries }\end{array}$ & $\begin{array}{c}\text { Additional } \\
\text { Capacity } \\
\text { (MW) }\end{array}$ & $\begin{array}{c}\text { Number of } \\
\text { Countries }\end{array}$ & $\begin{array}{c}\text { Additional } \\
\text { Capacity } \\
\text { (MW) }\end{array}$ & $\begin{array}{c}\text { Number of } \\
\text { Countries }\end{array}$ & $\begin{array}{c}\text { Additional } \\
\text { Capacity } \\
\text { (MW) }\end{array}$ \\
\hline \hline Coal & 4 & 57,498 & 4 & 53,625 & 4 & 57,244 \\
Diesel & 1 & 2,825 & 0 & 0 & 0 & 0 \\
Gas & 9 & 149,435 & 9 & 135,432 & 9 & 130,490 \\
Hydro & 5 & 36,887 & 5 & 57,844 & 5 & 61,434 \\
Geo & 6 & 12,476 & 6 & 15,046 & 6 & 15,651 \\
Wind & 4 & 8,504 & 5 & 11,509 & 8 & 15,156 \\
Solar & 0 & 0 & 0 & 0 & 0 & 0 \\
Bio & 3 & 4,569 & 3 & 2,659 & 2 & 450 \\
Total & & 272,193 & & 276,114 & & 280,425 \\
\hline
\end{tabular}

In Table 3, for each scenario, the first column indicates the number of countries which should develop the corresponding type of power generation capacity. The second column indicates the total amounts of capacities developed for the type of power generation capacity.

In the three scenarios, the policy regime of power trade in the region gradually relaxes, from no power trade allowed, to allowing $20 \%$ of demand to be met by power trade, and then to $50 \%$ of demand to be met by power trade. Table 3 presents how power generation capacities are developed differently in response to changes in power trade policy.

Certain trends and stylized facts could be observed from Table 3, as policy regime shifts in this order. First, the required amount of new natural gas power plants is reduced significantly over the increased possibility of power trade. Second, the amounts of renewable energy such as hydro, geothermal, and wind developed for power generation increase significantly over the increased possibility of power trade. Third, biomass power generation, which uses domestic biomass resources, is less needed as power trade allows the country to draw from cheaper sources in other countries. Fourth, solar PV power generation is not developed in any of the three scenarios, indicating that either the costs or the efficiency of the technology needs to be further improved. The current assumption that the costs of solar PV decrease $4.6 \%$ annually is insufficient to render the technology matured for the ASEAN region. 
There are a few reasons why natural gas appears to be the dominant energy source for power generation in future in the region. First, power generation using natural gas is far more competitive in terms of capital cost than other means such as coal or hydropower. Second, the power generation technology of natural gas is more efficient with lower carbon emissions than other thermal power generation technologies. Since the model considers the cost of carbon emissions, the relatively low amount of carbon emissions by natural gas makes the levelized cost of natural gas power generation even more competitive. Third, natural gas power generation also has higher load factor than hydropower, which contributes to a lower levelized cost of natural gas power generation (See Table A2 for reference). The above three reasons render natural gas more competitive against its two main competitors - coal and hydropower. In addition, since natural gas is a globally traded energy commodity like crude oil, the theoretical potential capacity of natural gas power generation is not bounded by local energy resources.

Changes in the power trade policy regime also impact the pattern of power trade in the region. Table 4 lists the three most important exporting countries in the two scenarios that allow power trade. The third column of the table summarizes the types of additional power generation capacity developed in the exporting country. And the fourth column lists the main trading partner of the exporting countries. The development of cross-border power grid in the region should therefore prioritize the linkage among the listed exporting countries and importing countries.

Table 4: Summary of Power Trade in the Region

\begin{tabular}{|c|c|c|c|}
\hline Scenario & $\begin{array}{l}\text { Main Exporting } \\
\text { Country }\end{array}$ & $\begin{array}{l}\text { Types of Additional } \\
\text { Capacity }\end{array}$ & $\begin{array}{l}\text { Main } \\
\text { Countries }\end{array}$ \\
\hline $\begin{array}{l}20 \% \\
\text { Power }\end{array}$ & Lao PDR & Hydro & $\begin{array}{l}\text { Viet Nam, Thailand, } \\
\text { Malaysia, Singapore }\end{array}$ \\
\hline \multirow{3}{*}{$\begin{array}{l}50 \% \\
\text { Power } \\
\text { Trade }\end{array}$} & $\begin{array}{l}\text { Malaysia } \\
\text { Cambodia }\end{array}$ & $\begin{array}{l}\text { Coal, Natural Gas, Hydro, } \\
\text { Geothermal, Wind } \\
\text { Natural Gas, Hydro }\end{array}$ & $\begin{array}{l}\text { Singapore, Philippines, } \\
\text { Indonesia } \\
\text { Viet Nam, Thailand, } \\
\text { Malaysia, Indonesia }\end{array}$ \\
\hline & $\begin{array}{l}\text { Lao PDR } \\
\text { Malaysia }\end{array}$ & $\begin{array}{l}\text { Natural Gas, Hydro, Wind } \\
\text { Coal, Natural Gas, Hydro, } \\
\text { Geothermal, Wind }\end{array}$ & $\begin{array}{l}\text { Viet Nam, Thailand } \\
\text { Singapore, Philippines, } \\
\text { Indonesia, Thailand }\end{array}$ \\
\hline & Thailand & $\begin{array}{l}\text { Coal, Natural Gas, } \\
\text { Geothermal, Wind }\end{array}$ & Viet Nam, Myanmar \\
\hline
\end{tabular}


According to the summarization in Table 4, a few observations could be made. In the $20 \%$ power trade scenario, the three countries which are rich in hydropower resource dominate the power export market in the region. In the $50 \%$ power trade scenario, it is of interest that Thailand has replaced Cambodia as the third most important exporter. One of the reasons this situation arises might be explained by the geographical position of Thailand - it links northern ASEAN countries to the southeastern ASEAN countries through the Malaysia peninsular. If one looks at the third column of main importing countries, Thailand is found to be a major importer of the power from Lao PDR and Malaysia and re-exports the power together with power from its own power generation capacities. This implies the potential of Thailand to play as a power trading hub in the region in future.

These observations about Thailand thus lead us to the important proposition that follows. The problem of where to build power generation capacities and to export power does not only depend on the costs of power generation in the country, but also on the geographical location of the country which best saves transmission costs and transmission losses.

More importantly, our simulation results lead us to the observation that opening power trade in the ASEAN countries would encourage the development of power generation from renewable sources, especially hydro, geothermal, and wind. In terms of time sequence of development, hydro should be developed first, and followed by geothermal and then wind.

\section{Conclusions}

The central question raised in this study is how to meet the growing power demand in ASEAN countries in the next two decades. The region is known to be rich in energy resources on the one hand, and experiencing fast economic growth which drives power demand on the other. Uneven distribution of energy resources and uneven pace of economic development among ASEAN countries complicates the question.

This study applies a dynamic linear programming model to simulate the optimal 
development paths of power generation capacities in the ASEAN region, assuming that the ASEAN Power Grid (APG) is in place. The model is based on Turvey \& Anderson (1977) and Chang \& Tay (2006) with the further development of many innovations. First, the model is extended from a single country model into a model of multiple countries with cross-border power trade. Second, the model incorporates the costs and losses of power transmission between countries. Third, the cost of carbon emissions from power generation activities is also taken into consideration in this model. Therefore, this model is based on the concept of levelized social cost of electricity.

Three scenarios are simulated to examine the impact of power trade policy regimes in the region. The first scenario assumes that no power trade is allowed. The second scenario assumes that $20 \%$ of a country's power demand could be met by power trade. And the third scenario assumes that $50 \%$ of a country's power demand could be met by power trade. The simulation results lead us to several interesting observations.

First, in the scenarios that open power trade, the ASEAN power grid enables active cross-border power trade between countries rich in resources and countries with high demand.

Second, with $50 \%$ power trade, the total cost to meet the growing electricity demand during 2010-2030 is reduced by around 3.9\% as compared to the no power trade scenario. In absolute terms, this saving is equivalent to USD 29 billion. With $20 \%$ of demand allowed to be met by power trade, the total cost to meet the growing electricity demand during 2010-2030 decreases by $3 \%$ as compared to the no power trade scenario. In absolute terms, the savings amount to USD 20.9 billion. The savings are net gains after all costs related to the ASEAN power grid have been paid off.

Third, in the $20 \%$ power trade scenario, the three countries which are rich in hydropower resource dominate the power export market in the region. In the $50 \%$ power trade scenario, Thailand notably replaces Cambodia as the third most important exporter. This is because of the geographical position of Thailand, which links northern ASEAN countries to the southeastern ASEAN countries through the Malaysia peninsular. The problem of where to build power generation capacity and to export power does not only depend on the costs of power generation in the country, but also on the geographical location of the country which best saves transmission costs and transmission losses.

Fourth, opening power trade in the ASEAN countries would encourage the 
development of power generation from renewable sources, especially hydro, geothermal, and wind.

Based on the above, the following policy implications could be drawn.

- Hydropower appears to be fully utilized when full-scale power trade across the region is allowed and produce the lowest cost option of power mix to meet the electricity demand in the region. This strengthens the necessity of integration of power infrastructure in the region such as the development of APG.

- Renewable energy for power generation appears to be utilized more under the scenarios with open power trade. Power trade policy regime is therefore important in this respect.

- Considering the energy security concern among the high import-dependency countries, the $50 \%$ power trade scenario seems to be more realistic in the region. And this power trade policy regime better supports the development of indigenous renewable energy in the region.

- The simulation results also provide references to the time sequence of power generation capacity development and cross-border power grid development in the region.

\section{References}

ASEAN Secretariat (2004), 'ASEAN Plan of Action for Energy Cooperation 20042009', Twenty Second ASEAN Ministers on Energy Meeting, Manila, Philippines, 9 June 2004.

ASEAN Ministers on Energy Meeting (2009), '2010 ASEAN Plan of Action for Energy Cooperation 2010-2015', ASEAN Ministers on Energy Meeting, Mandalay, Myanmar, July 2009.

Asia Development Bank (ADB) (2009), Energy Outlook for Asia and the Pacific. Manila: ADB.

Asia Pacific Energy Research Center (2004), Electric Power Grid Interconnections in the APEC Region. Tokyo: Asia Pacific Energy Research Center.

Atchatavivan, P. (2006), 'ASEAN Energy Cooperation: An Opportunity for Regional Sustainable Energy Development', in Moomaw, W. and L. Susskind (eds.) Papers on International Environmental Negotiation, Vol. 15. Ensuring a Sustainable Future, MIT-Harvard Disputes Program. 
Economic Consulting Associates (ECA) (2010), 'The Potential of Regional Power Sector Integration Greater Mekong Subregion (GMS) Transmission \& Trading Case Study', Submitted to ESMAP January 2010. London: ECA.

EU SEC (2008), Energy Sources, Production Costs and Performance of Technologies for Power Generation, Heating and Transport. Brussels: EU.

The Institute of Energy Economics, Japan, the ASEAN Center for Energy, and Energy Supply Security Planning for the ASEAN (2009), 'The Second ASEAN Energy Demand Outlook', Paper for the ASEAN SOE Leaders and the Ministry of the Economy, Trade and Industry, Japan. March 2009

The Institute of Energy Economics, Japan, the ASEAN Center for Energy, and Energy Supply Security Planning for the ASEAN (2011): The Third ASEAN Energy Outlook. Paper for the ASEAN SOE Leaders and the Ministry of the Economy, Trade and Industry, Japan. February 2011.

Chang, Y. and T. H. Tay (2006), 'Efficiency and Deregulation of the Electricity Market in Singapore', Energy Policy 34, pp.2498-2508.

International Energy Agency, and Nuclear Energy Agency (2010): Projected Cost of Generating Electricity: 2010 Edition. Paris: IEA and NEA.

Lidula, N. W. A., N. Mithulananthan, W. Ongsakul, C. Widjaya, and R. Henson (2007), 'ASEAN towards Clean and Sustainable Energy: Potentials, Utilization, and Barriers', Renewable Energy 32, pp.1441-1452.

Turvey, R. and D. Anderson (1977), Electricity Economics: Essays and Case Studies. Baltimore and London: The John Hopkins University Press.

Varun, I., K. Bhat, R. Prakash (2009), 'LCA of Renewable Energy for Electricity Generation Systems - A Review', Renewable and Sustainable Energy Reviews 13, pp.1067-1073.

Watcharejyothin, M., and R.M. Shrestha (2009), 'Effects of cross-border power trade between Laos and Thailand: Energy security and environmental implications', Energy Policy 37, pp.1782-1792.

World Energy Council (2010), 2010 Survey of Energy Resources. London: World Energy Council.

Yu, X. (2003), 'Regional Cooperation and Energy Development in the Greater Mekong Sub-region', Energy Policy 31, pp.1221-1234.

Yu, Z., B. H. Bowen, F. T. Sparrow, V. Siriariyaporn and L. Yu (2005), 'Integrated Energy Resources Planning for the ASEAN Countries and Southern China', Oil, Gas \& Energy Law Intelligence, 3(4), pp.1-12.

Zhai, Y. (2008), 'ADB's Role in Supporting Power Sector Restructuring in the Philippines - Electricity Market Development Project', presentation slides for the Orientation Program for DMC officials, ADB, October 2008.

Zhai, Y. (2009), 'Roadmap for Energy and Power Integration in the Greater Mekong Subregion (GMS)', presentation slides for the Conference on Energy Development in the Greater Mekong Subregion, Phnom Penh, July 2009 


\section{Appendix A. Input Data of the Model and Sources of Data}

Table A1: Existing Power Generation Capacity of ASEAN Countries (Base year 2009, Unit: MW)

\begin{tabular}{|c|c|c|c|c|c|c|c|c|c|c|}
\hline & Brunei & Cambodia & Indonesia & Lao PDR & Malaysia & Myanmar & Philippines & Singapore & Thailand & Viet Nam \\
\hline Coal & 0 & 0 & 12203 & 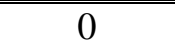 & 9068.4 & 0 & 5584.4 & 0 & 10719.2 & 3301.7 \\
\hline Diesel & 5.8 & 372 & 3328 & 50 & 685.4 & 279.08 & 1330.4 & 2511.2 & 269.3 & 580.5 \\
\hline Natural Gas & 753 & 0 & 10929 & 0 & 13380.2 & 980.92 & 3387.2 & 7934.8 & 32088.6 & 5795.9 \\
\hline Hydro & 0 & 13 & 4872 & 1805 & 2107 & 1460 & 3291 & 0 & 3488 & 5500 \\
\hline Geothermal & 0 & 0 & 1189 & 0 & 0 & 0 & 1953 & 0 & 0.3 & 0 \\
\hline Wind & 0 & 0 & 1 & 0 & 0 & 0 & 33 & 0 & 0.4 & 8 \\
\hline Solar PV & 0 & 0 & 0 & 0 & 0 & 0 & 1 & 0 & 10 & 0 \\
\hline Biomass & 0 & 5.78 & 0 & 0 & 0 & 0 & 0 & 20 & 800 & 0 \\
\hline
\end{tabular}

Sources: EIA website and IEA website

Table A2: CAPEX, OPEX, Life, and Availability of Power Generation Assets

\begin{tabular}{|c|c|c|c|c|c|c|c|c|}
\hline & Coal* & Diesel & Natural Gas & Hydro** & Geothermal & Wind & Solar PV & Biomass \\
\hline CAPEX (Million USD/MW) & 2.079 & 1.139 & 1.054 & 4.933 & 6.18 & 2.187 & 5.013 & 4.027 \\
\hline OPEX (USD/MWh) & 31.86 & 229.75 & 43 & 4.32 & 14.23 & 20.58 & 19.52 & 28.87 \\
\hline Life (Years) & 40 & 30 & 30 & 80 & 30 & 25 & 25 & 25 \\
\hline Load Factor (Percentage of A Year) & 0.85 & 0.85 & 0.85 & $0.23-0.64$ & 0.95 & 0.3 & 0.11 & 0.85 \\
\hline Carbon Emissions (ton/MWh) & 1.0 & 0.8 & 0.5 & 0.001 & 0.05 & 0.01 & 0.05 & 0.05 \\
\hline
\end{tabular}

Note: * Due to the consideration of abundance in coal resources, countries including Indonesia, Malaysia, Thailand, and Viet Nam are assumed to have $30 \%$ lower CAPEX and OPEX in coal-fired power generation.

** Due to the consideration of abundance in hydropower resources, countries including Cambodia, Indonesia, Lao PDR, Malaysia, Myanmar, and Philippines are assumed to have 30\% lower CAPEX and OPEX in hydropower generation.

Sources: IEA (2010) and EU SEC (2008) 
Table A3: Energy Resources for Power Generation in ASEAN Countries (Unit: MW)

\begin{tabular}{|c|c|c|c|c|c|c|c|c|c|c|}
\hline & Brunei & Cambodia & Indonesia & Lao PDR & Malaysia & Myanmar & Philippines & Singapore & Thailand & Viet Nam \\
\hline Coal & 15000 & 15000 & 50000 & 15000 & 50000 & 30000 & 30000 & 15000 & 50000 & 50000 \\
\hline Diesel & 15000 & 15000 & 15000 & 15000 & 15000 & 15000 & 15000 & 15000 & 15000 & 15000 \\
\hline Natural Gas & 15000 & 15000 & 50000 & 15000 & 50000 & 30000 & 30000 & 30000 & 50000 & 50000 \\
\hline Hydro & 0 & 10300 & 75459 & 18000 & 29000 & 0 & 13097 & 0 & 700 & 2170 \\
\hline Geothermal & 0 & 0 & 27000 & 0 & 67 & 930 & 2379 & 0 & 5.3 & 270 \\
\hline Wind & 0 & 452 & 7404 & 1600 & 452 & 1600 & 7404 & 0 & 1600 & 452 \\
\hline Biomass & 0 & 700 & 49810 & 0 & 29000 & 4098 & 200 & 50 & 7000 & 400 \\
\hline
\end{tabular}

Sources: Lidula, et al. (2007) and WEC Survey of Energy Resources 2010

Table A4: Power Demand and Duration of the Demand in ASEAN Countries

\begin{tabular}{|c|c|c|c|c|c|c|c|c|c|c|}
\hline & $\begin{array}{c}\text { Brune } \\
\mathbf{i} \\
\end{array}$ & $\begin{array}{c}\text { Cambodi } \\
\mathbf{a} \\
\end{array}$ & $\begin{array}{c}\text { Indonesi } \\
\mathbf{a} \\
\end{array}$ & $\begin{array}{r}\text { Lao } \\
\text { PDR } \\
\end{array}$ & $\begin{array}{c}\text { Malaysi } \\
\mathbf{a} \\
\end{array}$ & $\begin{array}{c}\text { Myanma } \\
\mathbf{r} \\
\end{array}$ & $\begin{array}{c}\text { Philippine } \\
\text { s } \\
\end{array}$ & $\begin{array}{c}\text { Singapor } \\
\mathrm{e} \\
\end{array}$ & $\begin{array}{c}\text { Thailan } \\
\text { d } \\
\end{array}$ & $\begin{array}{r}\text { Viet } \\
\text { Nam } \\
\end{array}$ \\
\hline Peak Demand (MW) & 454.7 & 291 & 23438 & 350 & 12990 & 1140 & 8766 & 5711 & 22586 & 11605 \\
\hline $\begin{array}{l}\text { Peak Duration } \\
\text { (Hours) }\end{array}$ & 4681.7 & 4925.2 & 4681.7 & 4745 & 4681.7 & 2428 & 4015 & 5840 & 4015 & 2428 \\
\hline Non-peak Demand (MW) & 257 & 85 & 5338 & 60 & 8388 & 162 & 3394 & 1324 & 8692 & 6862 \\
\hline $\begin{array}{l}\text { Non-Peak Duration } \\
\text { (Hours) }\end{array}$ & 4078.3 & 3834.8 & 4078.3 & 4015 & 4078.3 & 6332 & 4745 & 2920 & 4745 & 6332 \\
\hline
\end{tabular}

Sources: HAPUA website; Indonesia Energy Handbook 2011; Electricite du Laos Annual Report 2010; and Zhai (2008, 2009) 
Table A5: Transmission Loss and Cost among ASEAN Countries

\begin{tabular}{ll|ll}
\hline & Transmission Loss (\%) & Transmission Cost (\$/MWh) \\
\hline \hline Distance* & $0-1600 \mathrm{~km}$ & 0.01 & 3 \\
& $>1600 \mathrm{~km}$ & 0.087 & 5 \\
& $>3200 \mathrm{~km}$ & 0.174 & 7.5 \\
\hline
\end{tabular}

Note:* Distance is estimated as the distance between Capital cities of countries.

Sources: Claverton Energy Research Group http://www.claverton-energy.com/ 